\title{
Planning Benefits Realization in a Collaborative University-Industry R\&D Funded Program
}

\author{
Gabriela Fernandes ${ }^{1}$, Eduardo B. Pinto ${ }^{2}$, Madalena Araújo ${ }^{1}$, Ricardo J. Machado ${ }^{1,2}$ \\ ${ }^{1}$ Centre ALGORITMI \\ University of Minho \\ Guimarães, Portugal \\ g.ferrnandes@dps.uminho.pt \\ ${ }^{2}$ CCG/ZGDV Institute \\ University of Minho \\ Guimarães, Portugal \\ eduardo.pinto@ccg.pt
}

\begin{abstract}
This paper presents a benefits management (BM) approach adopted during the planning of a collaborative university-industry R\&D funded program, named IC-HMI Program, in order to pursue benefits realization. The BM approach embraced four main phases: 'Identify expected benefits'; 'Plan benefits realization'; 'Pursue benefits realization'; and 'Transfer and ensure benefits realization', each one comprising key activities that should be performed with a clear set of outputs to be generated. Particular focus is given to the benefits identification, and to the development of a Benefit Breakdown Structure (BBS), assuming the key role of such a formatting technique to target project benefits. It is the first and critical step in the BM process. Based on a review of literature, and the three research methods adopted during the IC-HMI case study analysis: a set of 33 benefits were identified, which can be used by professionals and academics as a checklist for benefits identification of their own initiatives. Additionally, the BBS implemented in IC-HMI program to qualify and better understand each benefit and its intrinsic properties, can be used to facilitate planning and benefits realization.
\end{abstract}

Keywords-Benefits management; university-industry; collaborative programs and projects

\section{INTRODUCTION}

There is little empirical evidence on how to manage program and project benefits $[1,2]$, especially in the particular context of collaborative university-industry Research and Development (R\&D) Funded programs or projects. While the literature on Benefits Management (BM) provides some advice, organizations need guidance on systematic approaches to manage benefits $[3,4]$.

Collaborative research programs and projects between industry and university are increasing [5], being encouraged by governments as a mean of enhancing national competitiveness and wealth creation [6]. University-industry collaborations are expected to play an important role through the development of innovative products, technologies and processes for industry [7].

A program is a set of projects that are somehow related and contributing to the same goal [8]. However, sometimes university-industry collaborations misunderstand the concept of program, and perceive programs as projects. Whichever is the situation, the applicability of the BM process is similar, and, as such the paper will address and present program and project management benefits indistinctly (program/project).

This research is sponsored by the Portugal Incentive System for Research and Technological Development. Project in co-promotion $\mathrm{n}^{\circ} 002814 / 2015$ (iFACTORY 2015-2018) and by the FCT (SFRH/BPD/111033/2015).
University and industry engage in R\&D collaborative efforts for several expectations of benefits from both sides. Benefit is understood as a measurable improvement that derives from the results obtained [9], i.e. it is a result of a perceived change that is seen as an improvement through the eyes of a stakeholder [2]. $\mathrm{BM}$ is perceived as a continuous process that includes the identification, planning, mensuration and follow-up of the benefits since the beginning of the program until the last benefit, previously specified, quantified and agreed-on, is realized [10, 11]. The Standard of Program Management from Project Management Institute [12] defines BM as a way of analyzing all available information about management strategies, internal and external factors and the motivations for the project with the purpose of identifying and categorizing all the expected benefits. These potential benefits should be registered, analyzed, classified and planned in detail.

A university-industry collaboration is perceived as a temporary organization with a collaborative work environment, within a specific context, with heterogeneous partners, collective responsibilities and, in many cases, with public funding support [13]. University-industry collaborations are based on interactive relationships, trust and commitment between partners aiming to create mutual value over time, which allows diffusion of creativity, ideas and skills, hence promoting a bilateral exchange of knowledge [14]. A university-industry collaboration exists to produce new results under a pre-defined research objective(s), within several limitations (time, cost and resources), resulting in a set of benefits for partners.

Collaborative university-industry R\&D programs/projects under funded contracts bring additional complexity and value to BM, since there are two different organizational structures with completely different cultures (Barnes, Pashby \& Gibbons, 2006) joined to pursue a set of contracted benefits, being the funds received conditioned upon the benefits realization.

This research aims to give some contribution to practice in this field by discussing the key BM activities planned, in a Collaborative University-Industry Research Project Program Case Study - named IC-HMI program, through its program management lifecycle. Particular focus is given to the identification of IC-HMI expected benefits since, as it is argued by Chih and Zwikael [15], formatting target project benefits is the first and critical step in the BM process. Therefore, more 
specifically, this paper seeks to answer the following research questions (RQ):

RQ1: What are the expected benefits of the IC- HMI Collaborative university-industry R\&D Program?

RQ2: What are the key BM activities planned to manage the identified benefits realization?

Moreover, the identified expected benefits are organized in a Benefit Breakdown Structure (BBS) to better qualify and understand the 'variables' that are involved in managing each particular benefit.

The paper follows a common structure. The second section discusses different BM approaches and collaborative universityindustry research benefits recognised in the literature. The third section describes the case study background and the efforts on improving project management and BM practices. The fourth section specifies the results obtained and discusses each research question. Finally, the conclusions as well as the limitations and suggestions for future work are discussed.

\section{BENEFITS MANAGEMENT}

Literature identifies several benefits associated to collaborative university-industry R\&D programs/projects. For example, for industry: 1) increase of market competitiveness [16-18]; 2) cost-effective research [17]; 3) acceleration of commercialization of new technologies $[17,18]$. For university: 4) increase the capacity of scientific production (industry and academic joint publications) $[16,17,19]$; 5) increase the capacity to attract new students, namely $\mathrm{PhD}$ students, in order to support the industry needs [18]. Or for both, industry and university: 6) acquisition of funds to hire human resources, purchase cutting-edge equipment, etc. $[18,20]$; and 7) technological breakthrough [21].

However, there are few BM approaches recognised in the literature [1, 22-24]. There is for example the Ward, Taylor [25] Cranfield process model of BM, which encompasses five stages: (1) identification and structure benefits; (2) plan benefits realization; (3) execute benefits plan; (4) review and evaluate results; and (5) assess potential for further benefits. This model is interactive and continues to be implemented beyond the end of the project, exploring the potential of future benefits and initiating a new plan for all the unexpected benefits that occur.

There is also the benefits realization approach designed by Thorp [26], which was built to deliver consistent and predictable benefits. Its foundations lay in two pillars: (1) the shift from a single project management to a program, portfolio and/or full cycle management; and (2) the existence of three necessary conditions for a successful model implementation: accountability, existence of metrics and proactive management. This model has a business-oriented structure, and consists of a set of processes, techniques and instruments that allow organizations to make an appropriate selection and management of benefits. In addition, it is perceived as a continuous process for obtaining benefits, allowing, at any moment, all sort of adjustments so that benefits can be achieved, according with the results tracking.
The Standard of Program Management from Project Management Institute [12] emphasizes that the potentially benefits should be registered, analyzed, classified and planned in detail, using a five core stage process: (1) benefits identification; (2) benefits analysis and planning; (3) benefits delivery; (4) benefits transition; and (5) benefits sustainment.

The Standard for Managing Successful Programs from Office of Government Commerce from UK [27] perceives BM process as a core and continuous action, that starts before the program/project is accepted. This process always takes into account the identification, monitoring and execution of benefits throughout the entire program/project, even after its completion. After having the vision statement clearly defined, this process unfolds into the following stages: establish and maintain a benefits management strategy; identify and map benefits; plan benefits realization; execute; review and evaluate realization; and optimize and look for other benefits.

By analyzing these models and approaches, it is possible to acknowledge that the literature does not provide a model for managing benefits in the context of collaborative universityindustry R\&D funded contracts. Therefore, these models were used as a starting point for planning the benefits realization of the IC-HMI program.

\section{CASE STUDY}

The results presented in this article are based on a case study - named IC-HMI program. The case study is assumed as one of the most used research methodologies by researchers following a qualitative approach [28]. Using case studies the researchers can focus in a particular phenomenon and discover crucial knowledge [29].

\section{A. Case Study Background}

The IC-HMI is a R\&D collaborative funded program resulted from a strategic partnership established between University of Minho (UMinho) and Bosch Car Multimedia Portugal S.A. (Bosch) in July 2012, regarding the development and production of advanced car multimedia solutions.

UMinho is currently among the most prestigious institutions of higher education in Portugal, and is in the top 100 universities under 50 years old $\left(75^{\text {th }}\right.$ position) worldwide. Founded in 1973, UMinho is engaged in the valorisation of the knowledge-research chain, development and innovation. UMinho stands out by the volume of publications and by the number of requested patents, as well as, by the high collaboration with industry, with around $250 \mathrm{R} \& \mathrm{D}$ contracts with industry signed annually.

Bosch is located in Braga, Portugal, and it was there founded in 1990. Over the years, Bosch became one of the biggest suppliers for automotive industry and the leading plant of the Car Multimedia division unit of Bosch Group. Presently, Bosch produces a wide portfolio of products, such as navigation systems, instrumentation systems, car radios, steering angle sensors, and electronic controllers. In 2015, Bosch achieved a 
turnover of around 516 million Euros, 99\% for export, with around two thousand jobs.

The IC-HMI program is the result of two public funded applications, INNOVCAR and IFACTORY. IC-HMI program foresees an investment of $€ 54.7$ million, from July 2015 to June 2018, with the admission of 94 new staff dedicated to R\&D in Bosch and 173 new researchers in UMinho. The IC-HMI program has planned 417 deliverables, the submission of 22 patent applications until June 2018 and 72 technical and scientific publications until June 2021.

The main benefits identified during the 'Program preparation' and included in the funding application were:

- Bosch: (i) business and products diversification as a driver for sustained growth; (ii) consolidation of Bosch reputation among customers and within the Bosch Group itself; (iii) increase the international accumulated sales volume (20192025 ) by around 1.1 billion euros, with new business areas and new portfolio of products generated in the IC-HMI context.

- UMinho: (i) recognition by the scientific community as a holder of the knowledge in technologies and methodologies developed within the different dimensions of the $R \& D$ program; (ii) strengthening the scientific and technological knowledge transfer into industry.

\section{B. Case Study Efforts on Improving Project Management and BM Practices}

UMinho and Bosch perceived since the beginning of the Program the value of project management and BM practices to manage such collaborative university-industry $R \& D$ funded programs; and therefore, invested in a supported infrastructure of the type Project Management Office - named Program and Project Management Office (PgPMO). According to Müller, Glückler [30] the proposed PgPMO has a serving role, since its main objective is to support the Program Coordination Board and Project Teams during the program and project management lifecycle. The PgPMO takes responsibility for some of the project managers' tasks in order to reduce the workload of individual project managers and to benefit from the accumulated expertise and economies of scale [31].

The PgPMO main responsibility, at the IC-HMI 'Program initiation' phase, was to propose to the Program Coordination Board the governance model for the IC-HMI program. The Program Coordination Board is composed by four people: the Program Directors, one from UMinho and another from Bosch, and the Program Managers, similarly one from UMinho and another from Bosch. In fact, each IC-HMI organization role has always a representative from Bosch and a representative from UMinho. The governance model proposed is based on a developed methodology especially devoted to program and project management of collaborative University-Industry R\&D funded contracts, named as PgPM methodology [32, 33].

The governance model presents the IC-HMI organizational structure, clarifying the functions and responsibilities of each organization member, as well as standardizing the main processes to support the management of the entire program and of its constituent projects. Specific guidance is given for each IC-HMI role, namely Steering Committee Member, Program Director, Program Manager, Project Manager, Program and Project Management Officer (PMO Officer) and Team Member, covering their main activities and responsibilities during the program and project life cycle.

The program and project management life cycle adopted is divided in four phases:

- 'Program preparation' occurs as the result of a formal or informal university-industry collaboration, in order to achieve a desired state within a set of new $R \& D$ projects from both organizations. Its main objectives are: to align a common strategy, to identify the program scope, and to strive for the necessary resources to support new R\&D projects, namely the financial support for the program (e.g., competitive funds).

- 'Program initiation' aims to guarantee the initial program planning and the alignment of the program objectives and outcomes with the stakeholders that will effectively get involved into program execution. Typically, collaborative R\&D university-industry programs involve many university researchers and collaborators from the industrial organization, with distinct expectations, experiences and mindsets. Another important objective is the creation of a program support office (PgMO) or its equivalent, namely to support the program governance.

- 'Program benefits delivery' the projects of the program are planned, integrated and managed to facilitate the delivery of the intended program benefits.

- 'Program closure' aims to execute a controlled closure of the program. This phase is also important to determine whether the collaboration can be sustained.

During the entire program management lifecycle, the Program Coordination Board is responsible for the Program BM, by defining, creating, maximizing, delivering and sustaining the benefits provided by the program (PMI, 2013).

\section{Research Methods}

During the case study conduction, three research methods were applied: observation, document analysis, and several unstructured focus groups in order to discuss the suitable BM approach to adopt, as well as the specific activities to be performed for managing the identified and agreed IC-HMI benefits. The focus groups were conducted with different ICHMI stakeholders, namely the Program manager, two Project Managers, and four PMO Officers. There is a high proportion of PMO Officers participation, for two reasons: (1) more availability, they are more aware of the BM practices implementation importance; and (2) their role, since they are the main elements responsible for improving and supporting program and project management practices, as well as BM practices. 
The preparation and conduction of the focus groups sessions are, in many aspects, similar to those that one can observe in interviews, for instance, preparing questions in advance and providing feedback on what one hears [34]. The focus group moderator (researcher) used auxiliary materials, namely the benefits list identified from literature review, to stimulate the opinion of the participants.

\section{RESUlTS AND DISCUSSION}

The following subsections present: (1) the identification of IC-HMI benefits and the Benefit Breakdown Structure developed, and (2) the BM plan developed for IC-HMI identified benefits realization.

\section{A. IC-HMI Benefits Identification}

The benefits gathered from literature was used as a checklist, and it was an important input to the identification of the benefits generated by IC-HMI program. The IC-HMI benefits were gathered through the three research methods: observation, document analysis and unstructured focus groups. The IC-HMI benefits list are presented in Table I, grouped by university: UMinho, industry: Bosch and both universityindustry: UMinho/Bosch, was validated during a focus group session.

While a checklist may be quick and simple to use, it is impossible to build an exhaustive one, and care should be taken to ensure the checklist is not used to avoid effort, during benefits identification, from stakeholders. The checklist should be reviewed continuously during the program execution and closure phase to incorporate new benefits identified and improve it for use in future programs.

TABLE I. IC-HMI PROGRAM BENEFITS LIST

\begin{tabular}{|c|c|c|c|}
\hline & $\mathbf{N}^{\mathbf{0}}$ & IC-HMI Benefit Description & References \\
\hline \multirow{17}{*}{ 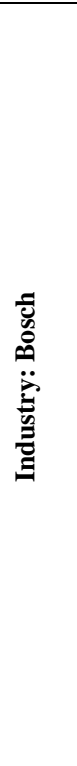 } & IC.B.1 & $\begin{array}{l}\text { Increase competitiveness of Bosch through the ability to attract new innovation projects, as well as } \\
\text { industrialization projects }\end{array}$ & {$[16-18]$} \\
\hline & IC.B. 2 & $\begin{array}{l}\text { Portfolio diversification: new products/services/processes (e.g. products and services supported in software and } \\
\text { applications for vehicles, transport systems and smart cities) }\end{array}$ & {$[5,17,18,20]$} \\
\hline & IC.B.3 & Acceleration of the commercialization of new technologies/products & {$[17,18]$} \\
\hline & IC.B.4 & Access to a wide network of international experts & {$[17,18]$} \\
\hline & IC.B.5 & Consolidation of Bosch reputation among clients and within Bosch Group & {$[17]$} \\
\hline & IC.B.6 & $\begin{array}{l}\text { Increase the number of Bosch's Portuguese suppliers, reducing dependence on Asian suppliers and associated } \\
\text { logistics costs, indirectly increasing Portuguese exports }\end{array}$ & [17] \\
\hline & IC.B.7 & Increase the number of patents ( 22 patents submissions targeted) & [5] \\
\hline & IC.B.8 & Cost-effective research & {$[17,18]$} \\
\hline & IC.B.9 & Sustained increase of the company's turnover between 2016 and 2020 & [17] \\
\hline & IC.B.10 & $\begin{array}{l}\text { Improvement of the profit margins and cost reductions as a result of an increase in efficiency provided by the } \\
\text { developed solutions }\end{array}$ & {$[18,20]$} \\
\hline & IC.B.11 & $\begin{array}{l}\text { Improvement of the key performance indicators (e.g. stock deviation, number of milk-runs per shift; productivity } \\
\text { in repacking area) }\end{array}$ & [18] \\
\hline & IC.B.12 & $\begin{array}{l}\text { Increase of exports resultanting from new products development (cumulative international sales between } 2019 \text { and } \\
2025 \text { of around } 1.1 \text { billion euros) }\end{array}$ & [17] \\
\hline & IC.B.13 & Resolution of several technical problems (e.g. products packaging, products storage, products identification, etc.) & {$[18,20]$} \\
\hline & IC.B.14 & Improvement of product quality & {$[20]$} \\
\hline & IC.B.15 & Reinforcement of Bosch's internal competences in its different business areas & {$[5,17]$} \\
\hline & IC.B.16 & Increase the industry's absorptive capacity for new knowledge & {$[18]$} \\
\hline & IC.B.17 & Acceleration of the industrialization of new developed processes & [5] \\
\hline \multirow{8}{*}{ 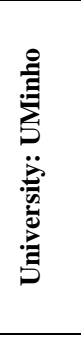 } & IC.B. 18 & $\begin{array}{l}\text { Recognition of UMinho in the academic community, as the holder of knowledge concerning the technologies and } \\
\text { methodologies developed in the different R\&D projects within the program }\end{array}$ & {$[17,18]$} \\
\hline & IC.B.19 & Source of income for universities (either public and/or private) & {$[5,17,18]$} \\
\hline & IC.B.20 & Affiliation with a safe environment to receive feedback on ideas/results/theories & {$[17]$} \\
\hline & IC.B.21 & Reinforcement of the university's know-how, in certain subjects, due to the intrinsic industry's characteristics & {$[17,18]$} \\
\hline & IC.B.22 & Reorientation of the UMinho research/development agenda in order to be aligned with the industry needs & {$[17,18,20,21]$} \\
\hline & IC.B.23 & $\begin{array}{l}\text { Increase the capacity for scientific production (industry and academic joint publications; } 72 \text { scientific publications } \\
\text { targeted) }\end{array}$ & [5], [16-19] \\
\hline & IC.B.24 & Attract new students to UMinho (bachelor/master/PhD) & {$[16-19]$} \\
\hline & IC.B.25 & Real world experience for students (opportunity to interact with Bosch practical problems) & [17] \\
\hline \multirow{8}{*}{ 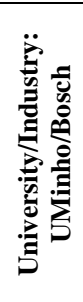 } & IC.B.26 & Acquisition of funds to hire researchers, purchase cutting-edge equipment, etc. & {$[5],[18,20]$} \\
\hline & IC.B.27 & Technological breakthrough (e.g. human machine interface, noise cancelation sensors) & [21] \\
\hline & IC.B.28 & Improvement of the innovation ability; ongoing follow up of technological changes & {$[18]$} \\
\hline & IC.B.29 & Increase in qualified employment through the recruitment of UMinho students & {$[6,17,18,20,21]$} \\
\hline & IC.B.30 & $\begin{array}{l}\text { Regional/local economic development, namely through the direct and indirect increase of production of goods and } \\
\text { services and export orientation of regional/local companies }\end{array}$ & [17] \\
\hline & IC.B.31 & Learning/continuous professional development (more qualified company staff and researchers) & {$[5,17]$} \\
\hline & IC.B.32 & Promotion of environment sustainability, by developing eco-friendly solutions & {$[17]$} \\
\hline & IC.B.33 & Reinforcement of the knowledge transfer from UMinho to Bosch & {$[18]$} \\
\hline
\end{tabular}


In order to promote a better understanding of the 'variables' that are involved in managing each particular benefit, and their purposes, as referred to above, it is crucial not only to identify them, but also to categorize the expected benefits. Therefore, an IC-HMI benefit breakdown structure (BBS) was developed.

The BBS helps the program stakeholders to look at many sources from which program benefits may arise. Figure 1 shows the BBS developed, where the IC-HMI benefits identified and listed in Table I, through deductive reasoning, analytical induction and expert judgement of the focus groups participants, were categorized concerning their:

- Typology: if the benefits are related to strategic, economic, operational or social benefits $[22,35]$.

- Nature: if the benefits are tangible or intangible, i.e. if they can be measured in an objective, quantitative, and even financial way or in a more subjective way and using qualitative measures [22].

- Incidence: if the benefits have direct or indirect incidence, i.e., the benefits take a clear action and repercussion on the program/project itself, or they act like a means to a bigger purpose that transcends the program/project itself [22].

- Time impact: if the benefits have short term or long-term impact, i.e., causing repercussions on the program/project immediately or having their impacts shown only after program/project's closure.

- Agent: if the benefits affect only industry, only university or both simultaneously.

- Scope: if the scope of action of each benefit is value creation, strategy, resources quality/performance, knowledge or interrelational [36]

\section{B. Planning Benefits Realization}

The BM approach adopted to manage the identified benefits resultant from the IC-HMI collaborative research program between UMinho and Bosch (Table I) uses the iterative principle of the four-step management called PDCA cycle (Plan, Do, Check, Act), designed by William Edwards Deming, oriented towards the control and continuous improvement of processes [37].

The PDCA principle provides clear and more responsive management procedures. The adoption of its assumptions allows the developed BM approach, to be perceived as systematic, practical and with intuitive usage.

The BM approach adopted in IC-HMI adapted the PDCA cycle into a BM continuous process with also four phases: 'Identify', 'Plan', 'Act', and 'Verify', corresponding to 'Identify expected benefits', 'Plan benefits realization', 'Pursue benefits realization', and 'Transfer and ensure benefits sustainability'. These phases are engaged with the Program and Project Management (PgPM) lifecycle adopted since the ICHMI 'Program preparation' phase [33], since the linkage between program/project management practices and BM practices is important [1].

This linkage is portrayed in Figure 2. The BM approach is based on the continuity and natural progress between the different phases and the chronological lines of action and it is only systematized in the form of a pictorial diagram. Therefore, elements used in the construction of the diagram have no operational semantics.

Benefit Breakdown Structure

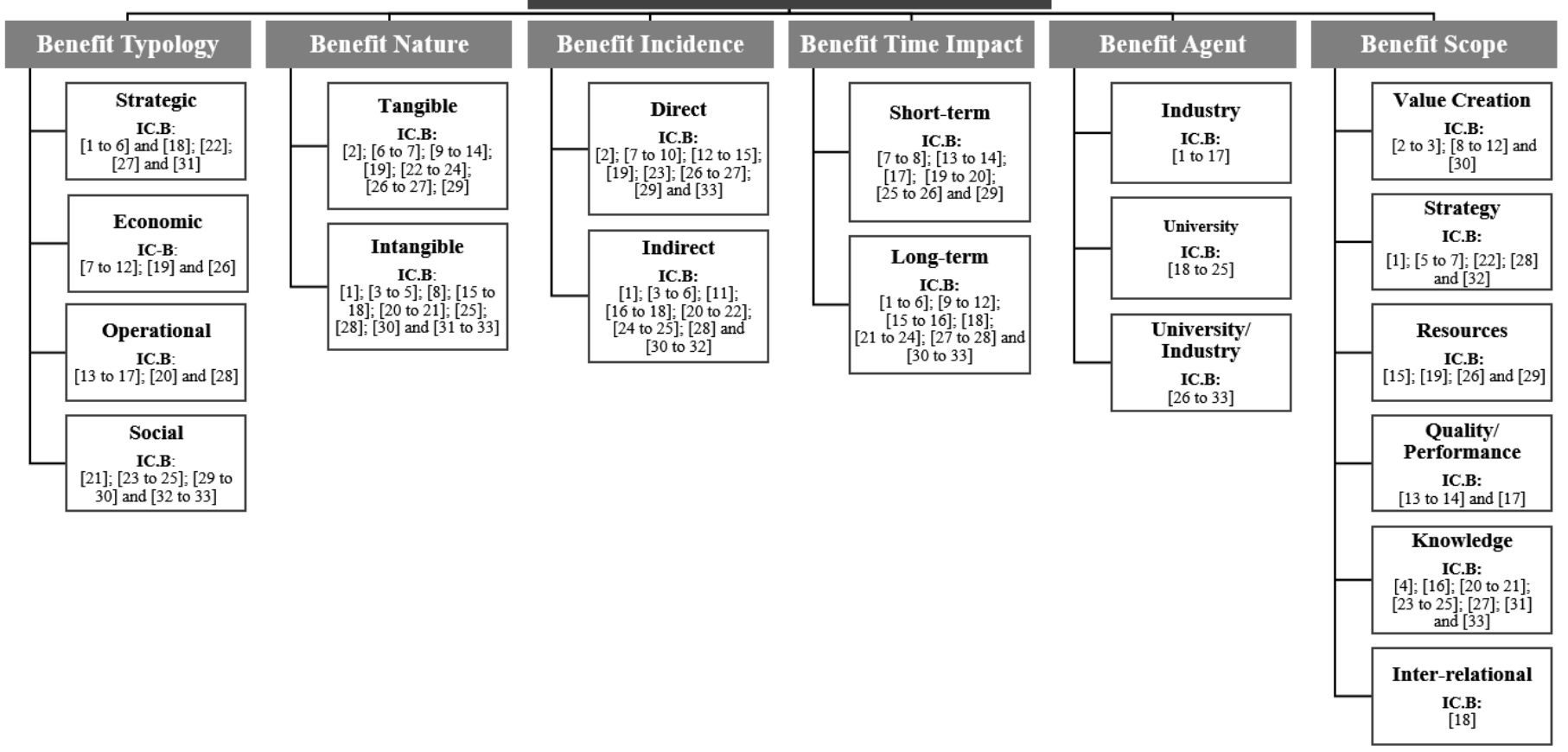

Fig. 1. IC-HMI Benefit breakdown structure. 
Table II summarizes the IC-HMI BM plan with a set of actions clearing the aim of each phase. These actions imply human resources, procedures and information that, when applied efficiently, are expected to translate into value for stakeholders. In addition, this BM approach aims to distinguish itself by: (1) turning the decision-making process based upon facts, (2) stimulating the engagement of all stakeholders, (3) promoting teamwork, and (4) focusing on the optimization of all the different activities involved in the approach.

Each BM approach phase engages differently with the PgPM lifecycle:

- 'Identify expected benefits' - occurs during the whole PgPM lifecycle, with higher effort during 'Program preparation' and 'Program initiation';

- 'Plan benefits realization' - begins its implementation at 'Program initiation' (where the main effort takes place) but it also comprises all phases of the PgPM lifecycle, since planning is implied and taken into account in every process of program/project management;

- 'Pursue benefits realization' - begins its implementation only during 'Program benefits delivery' and its effort is extended to 'Post-program'; and

- 'Transfer and ensure benefits sustainability' - also initiates its implementation during 'Program benefits delivery' and its effort increases, progressively, reaching its peak of implementation during 'Program closure'. Unlike other phases, 'Transfer and ensure benefits sustainability' as well as 'Pursue benefits realization' continue their efforts beyond 'Program closure', the last phase of the PgPM lifecycle [33].

\section{1) Identify Expected Benefits}

The primarily goal of the phase 'Identify expected benefits', as the name suggests, is to identify benefits and gather them in a benefits register. However, before benefits identification, it is important to define the strategic vision of the established collaborative partnership, so its concepts will lay ground for common behaviors and actions.

The established expected benefits should be SMART:

- Specific - be expressed in a concise and accurate form;

- Measurable - be defined by a method that allows them to be measured and analyzed in terms of value;

- Attainable - be achievable;

- Realistic - be intended to accomplish ends higher than its means to achieve it;

- Time-bounded - be defined by having into account the reasonable time to achieve it.

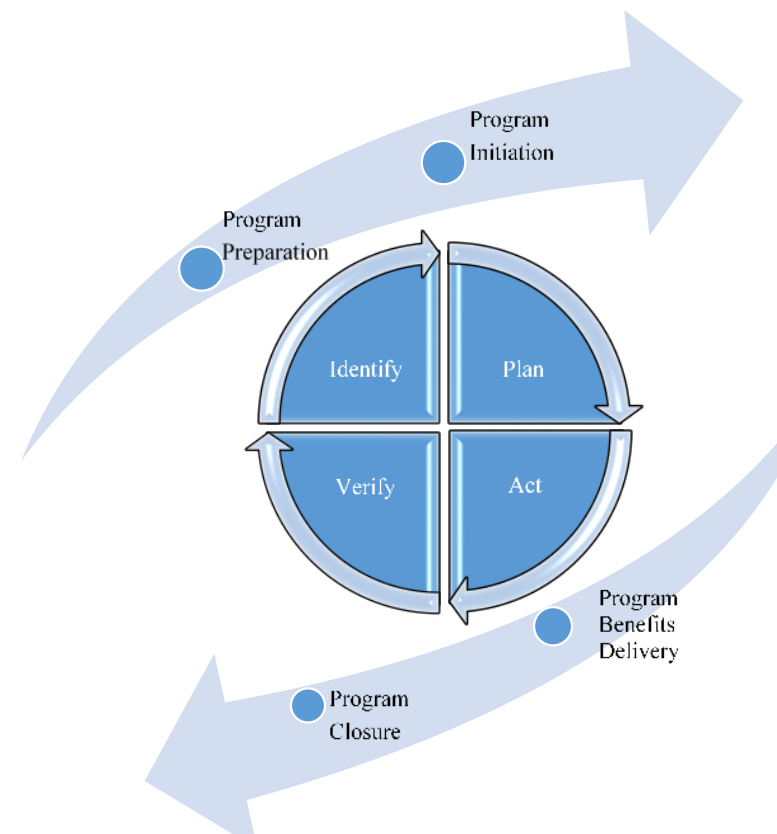

Fig. 2. BM approach mapped with the PgPM lifecycle.

TABLE II. IC-HMI BM PLAN FOR BENEFITS REALIZATION

\begin{tabular}{|c|c|}
\hline Identify & Plan \\
\hline Identify Expected Benefits & Plan Benefits Realization \\
\hline 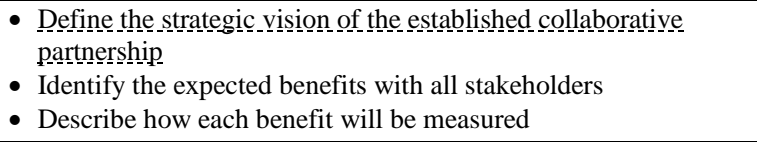 & $\begin{array}{l}\text { - Categorize the identified benefits } \\
\text { - Prioritize the expected benefits } \\
\text { - Link the expected benefits to the projects of the program } \\
\text { Develop the benefits realization plan }\end{array}$ \\
\hline Verify & Act \\
\hline Transfer and Ensure Benefits Sustainability & Pursue Benefits Realization \\
\hline $\begin{array}{l}\text { - Keep track of benefits and critical factors for the benefits } \\
\text { realization } \\
\text { - Identify gaps by analyzing if each benefits realization measure } \\
\text { established meets the planned target and, if not, list all missed } \\
\text { opportunities } \\
\text { - Transfer the program results into the organizations } \\
\text { - Ensure that benefits continue to be monitored when the program } \\
\text { close }\end{array}$ & 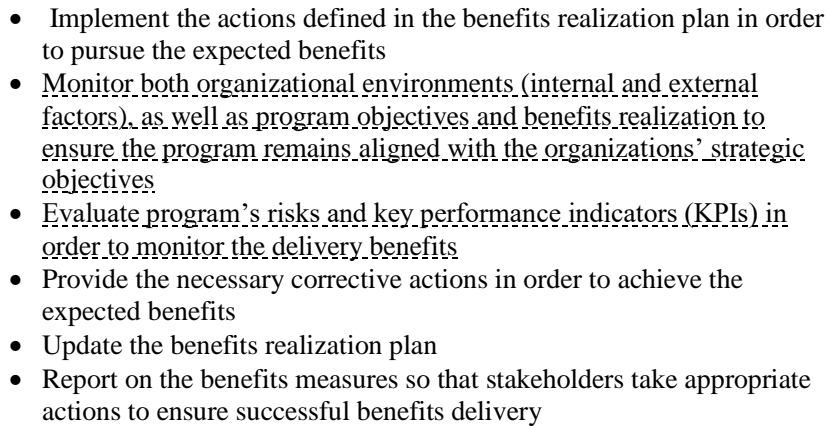 \\
\hline
\end{tabular}


During this phase, benefits should be thoroughly described to what concerns how and when they will be measured. Then the appropriate measures should be defined (e.g., KPIs) for each identified benefit. Table III summarizes the BM phase 'Identify expected benefits', with a set of actions clarifying its aims, as well as the outputs generated by each action.

TABLE III. 'IDENTIFY EXPECTED BENEFITS' PHASE

\begin{tabular}{|l|l|}
\hline \multicolumn{2}{|c|}{ Identify Expected Benefits } \\
\hline \multicolumn{1}{|c|}{ Aims } & \multicolumn{1}{c|}{ Outputs } \\
\hline $\begin{array}{l}\text { Define the strategic } \\
\text { vision of the established } \\
\text { collaborative partnership }\end{array}$ & $\begin{array}{l}\bullet \text { University-industry collaboration strategic } \\
\text { vision defined } \\
\text { Decisions and behaviors aligned with the } \\
\text { strategic vision }\end{array}$ \\
\hline Establish the BM plan & $\begin{array}{l}\bullet \text { A methodology established with processes, } \\
\text { tools and techniques to manage the benefits } \\
\text { during the program/project lifecycle }\end{array}$ \\
\hline $\begin{array}{l}\text { Identify the expected } \\
\text { benefits with all } \\
\text { stakeholders }\end{array}$ & $\begin{array}{l}\bullet \text { Benefits register, with a list of benefits defined } \\
\bullet \text { SMART benefits }\end{array}$ \\
\hline $\begin{array}{l}\text { Describe how each } \\
\text { benefit will be measured }\end{array}$ & $\begin{array}{l}\bullet \text { Appropriate measures (KPIs) for each benefit } \\
\text { defined; the appropriate process to measure } \\
\text { and when to do it } \\
\bullet \text { Benefits register updated }\end{array}$ \\
\hline
\end{tabular}

\section{2) Plan Benefits Benefits}

The second phase 'Plan benefits realization' is divided into four main activities, as summarized in Table IV.

The first activity in this phase should be to categorize the expected benefits through the development of a benefits breakdown structure (BBS). Secondly, it is important to prioritize the expected benefits. Collaborative universityindustry $\mathrm{R} \& \mathrm{D}$ programs/projects have high levels of risk, uncertainty and success volatility; managing benefits should be shaped around forums for debate, with regular meetings and the presence of all different hierarchies involved in the program/project, in order to promote a discussion of their expectations, desires and goals. This activity is crucial to identify, prioritize and manage expectations and, therefore, to cultivate a prolific relationship.

The IC-HMI BM approach adopted includes a prioritization method, which is an adaptation of the Moscow technique, due to its easiness, quickness and higher user confidence [38], by prioritizing the benefits accordingly to:

- Must have - mandatory benefits, must be achieved (e.g., contracted benefits with the funding agency);

- Should have - benefits that should be realized due to its level of relevance, though not mandatory;

- Could have - benefits that could be realizable but are optional;

- Would have - benefits important for future collaborations.

Thirdly, map the benefits to each project of the program in order to pursue the sources of each benefit identified. Lastly, a benefits realization plan should be developed, establishing when and how the benefits will be delivered. Actions that leverage the realization of each expected benefit should be defined. A cost-benefit analysis between the effort necessary to leverage a critical factor and the payback of the benefit generated should also be performed to support the decision of what actions should be taken to leverage the benefits critical factors.

TABLE IV. 'PlAN BENEFITS REALIZATION' PHASE

\begin{tabular}{|l|l|}
\hline \multicolumn{1}{|c|}{ Pims } & \multicolumn{1}{c|}{ Outputs } \\
\hline $\begin{array}{l}\text { Categorize the } \\
\text { identified benefits }\end{array}$ & $\begin{array}{l}\bullet \text { Benefits register updated, with the benefits } \\
\text { categorized in a BBS }\end{array}$ \\
\hline $\begin{array}{l}\text { Prioritize the } \\
\text { expected benefits }\end{array}$ & $\begin{array}{l}\bullet \text { Benefits register updated, with the prioritized } \\
\text { benefits using 'Must have', 'Should have', 'Could } \\
\text { have' and 'Would have' as a scale }\end{array}$ \\
\hline $\begin{array}{l}\text { Link the expected } \\
\text { benefits to the } \\
\text { projects of the } \\
\text { program }\end{array}$ & $\begin{array}{l}\bullet \text { Benefits register updated, with the benefits } \\
\text { realization expectancy mapped throughout for each } \\
\text { project of the program or the program as a whole }\end{array}$ \\
\hline $\begin{array}{l}\text { Develop the } \\
\text { benefits } \\
\text { realization plan }\end{array}$ & $\begin{array}{l}\bullet \text { Actions to enhance the critical factors in order to } \\
\text { pursue the benefits realization } \\
\bullet \text { Cost-benefit analysis on the actions that should be } \\
\text { applied in order to deliver the expected benefits } \\
\bullet \text { Metrics established on how and when the benefits } \\
\text { will be delivered } \\
\bullet \text { Each benefit responsible and accountable identified } \\
\bullet \text { Benefits realization plan }\end{array}$ \\
\hline
\end{tabular}

\section{3) Pursue Benefits Realization}

The main objective of this phase is to implement the necessary actions to 'Pursue the benefits realization'. The phase is divided into six main activities, presented in Table $\mathrm{V}$.

\section{4) Transfer and Ensure Benefits Sustainability}

The main objective of the phase 'Transfer and ensure benefits sustainability' is to ensure the monitoring of expected benefits and critical factors for the realization of benefits. In order to achieve this ongoing tracking, there should be a close control of how and when the benefits will be delivered in order to establish metrics to define and assess them during 'Program benefits delivery', 'Program closure', but also during the 'Postprogram'. The phase is divided into four key activities (see Table VI).

During the 'Program closure' and 'Post-program', it is important to identify gaps by analyzing if the benefit realization measure has met the planned target and, if not, list all missed opportunities, and report lessons learned. Besides this, an analysis of the level of accomplishment of the stakeholder's expectations should also be made. Therefore, all the benefits should be rated, in a scale of 1 (low) to 4 (high), in order to analyze the degree of the benefits realization and, whether or not, the stakeholder's expectations have been met.

This phase also aims to ensure that the handover of knowledge and insights acquired during the program/project lifecycle is achieved and, that the results obtained within the program are being correctly exploited and extrapolated by both organizations partners, Bosch and UMinho. 
Finally, it is important to guarantee that there is, still, benefits monitoring even when the program/project closes. There are benefits that can only be perceived and/or achieved after the end of the program/project, and BM is a cyclic process that only ends when all the expected benefits are achieved. Therefore, it is important to implement a system to communicate future actions and needs in order to accomplish benefits whose timeline is longer than the program closure, and also, to have a system that collects ideas to aid in future collaborations.

TABLE V. 'PURSUE BENEFITS REALIZATION' PHASE

\begin{tabular}{|l|l|}
\hline \multicolumn{2}{|c|}{ Pursue Benefits Realization } \\
\hline \multicolumn{1}{|c|}{ Aims } & \multicolumn{1}{c|}{ Outputs } \\
\hline $\begin{array}{l}\text { Implement the actions defined in } \\
\text { order to pursue the expected } \\
\text { benefits }\end{array}$ & $\begin{array}{l}\bullet \text { Benefits register updated, namely } \\
\text { with the record of the actions taken to } \\
\text { trigger the critical factors for benefits } \\
\text { realization }\end{array}$ \\
\hline $\begin{array}{l}\text { Monitor organizational } \\
\text { environments (internal and } \\
\text { external factors), as well as } \\
\text { program objectives and benefits } \\
\text { realization to ensure the program } \\
\text { benefits remains aligned with the } \\
\text { organizations' strategic objectives }\end{array}$ & $\begin{array}{l}\bullet \text { Benefit audit reports } \\
\text { benefits list }\end{array}$ \\
\hline $\begin{array}{l}\text { Evaluate program's risks and key } \\
\text { performance indicators (KPIs) in } \\
\text { order to monitor the delivery } \\
\text { benefits }\end{array}$ & $\begin{array}{l}\bullet \text { Benefits register updated, namely the } \\
\text { identification of the program's risks } \\
\text { that might impact the benefits } \\
\text { realization }\end{array}$ \\
\hline $\begin{array}{l}\text { Provide the necessary corrective } \\
\text { actions in order to achieve the } \\
\text { expected benefits }\end{array}$ & $\begin{array}{l}\bullet \text { Benefits realization plan updated, } \\
\text { with new actions to perform the } \\
\text { benefits realization } \\
\bullet \text { Benefits register updated, namely } \\
\text { with the record of the corrective } \\
\text { actions }\end{array}$ \\
\hline $\begin{array}{l}\text { Report on the benefits measures } \\
\text { appropriate actions to ensure } \\
\text { successful benefits delivery }\end{array}$ & $\begin{array}{l}\bullet \text { Cockpit chart, provided to all } \\
\text { stakeholders, containing the benefits } \\
\text { status } \\
\text { Benefits register updated } \\
\bullet \text { Events implemented, whose main } \\
\text { goal is to provide each project team } \\
\text { involved in the program with insights } \\
\text { and knowledge exchange about } \\
\text { realized/expected benefits }\end{array}$ \\
\hline $\begin{array}{l}\bullet \text { Benefits realization plan updated, to } \\
\text { reflect the changes in the projects of } \\
\text { the program }\end{array}$ \\
\hline
\end{tabular}

TABLE VI. 'TRANSFER AND ENSURE BENEFITS SUSTAINABILITY' PHASE

\begin{tabular}{|l|l|}
\hline \multicolumn{2}{|c|}{ Transfer and Ensure Benefits Sustainability } \\
\hline \multicolumn{1}{|c|}{ Aims } & \multicolumn{1}{c|}{ Outputs } \\
\hline $\begin{array}{l}\text { Keep track of benefits } \\
\text { and critical factors }\end{array}$ & $\begin{array}{l}\bullet \text { Cockpit chart containing the benefits status, } \\
\text { as well as a dashboard containing all critical } \\
\text { factors for the realization of each benefit }\end{array}$ \\
\hline $\begin{array}{l}\text { Identify gaps by } \\
\text { analyzing if each } \\
\text { benefits realization } \\
\text { measure established } \\
\text { meets the planned } \\
\text { target and, if not, list all } \\
\text { missed opportunities }\end{array}$ & $\begin{array}{l}\text {-Lessons learned registered during the BM } \\
\text { process } \\
\text { Review the level of accomplishment of the } \\
\text { stakeholder's expectations (verification if the } \\
\text { benefit realization meets the planned target) }\end{array}$ \\
\hline $\begin{array}{l}\text { Transfer the program } \\
\text { results into the } \\
\text { organizations }\end{array}$ & $\begin{array}{l}\bullet \text { Transition plans developed to facilitate the } \\
\text { ongoing benefits realization } \\
\bullet \text { List of team members, within the } \\
\text { organization, accountable for the exploitation } \\
\text { of the results obtained during the program } \\
\bullet \text { All necessary information handover in order } \\
\text { to allow the exploitation of the results }\end{array}$ \\
\hline $\begin{array}{l}\bullet \text { A system developed to communicate future } \\
\text { actions and needs in order to realize benefits } \\
\text { montinue to be } \\
\text { program close }\end{array}$ & $\begin{array}{l}\text { whose timeline is longer than the program } \\
\text { closure; and to provide a platform where } \\
\text { ideas can be collected to aid in future } \\
\text { collaborative programs }\end{array}$ \\
\hline
\end{tabular}

\section{CONCLUSION}

The contribution of this paper is twofold. Firstly, this research builds knowledge in the area of BM, for which there is limited understanding (Badewi, 2016; Breese, 2012). It presents a BM approach adopted in a collaborative university-industry R\&D program between University of Minho and Bosch Car Multimedia, named IC-HMI, which can be adapted by professionals and academics to other university-industry $R \& D$ collaborations. Briefly, the BM approach embraces four main phases: 'Identify expected benefits'; 'Plan benefits realization'; 'Pursue benefits realization'; and 'Transfer and ensure benefits realization', each one comprising key activities that should be performed with a clear set of outputs to be generated (see Table II). The BM approach is also linked to the program and project management approach, PgPM implemented within IC-HMI program $[32,33]$. This linkage allowed concluding that some of $\mathrm{BM}$ activities are common to the whole program management $(22 \%)$ and therefore, not exclusive of BM, which can be a driver for the implementation of BM.

Secondly, the research gives a great contribution to practice by providing program managers with a compilation of a list of 33 university-industry R\&D collaboration benefits (see Table I), which can be used by professionals and academics, as a checklist for the identification of the benefits generated by their own programs/projects. Additionally, for a clear and better understanding of the benefits, a BBS (see Fig. 1) was developed. The identified benefits of IC-HMI in Table I were categorized into different criteria: typology, nature, incidence, time impact, agent and scope. For example, concerning benefits typology, benefits were categorized into 'strategic', 'economic', 'operational' and 'social' benefits. 
Further research could be conducted by identifying the critical factors that might contribute for the realization of each benefit, in order to more easily perform an appropriate selection of actions that will trigger the specific critical factor and therefore the stakeholders' expected benefits. Additionally, further case study applications of the BM approach adopted in IC-HMI will be very valuable, namely for the continuous improvement of the BM approach used in this particular case study.

\section{REFERENCES}

[1] A. Badewi, "The impact of project management (PM) and benefits management (BM) practices on project success: Towards developing a project benefits governance framework," International Journal of Project Management, vol. 34(4), pp. 761-778, 2016.

[2] R. Breese, "Benefits realisation management: Panacea or false dawn?," International J. of Project Management, vol. 30(3), pp. 341-351, 2012.

[3] T. Nomakuchi, and M. Takahashi, "A Study about Project Management for Industry-University Cooperation Dilemma," Procedia Computer Science, vol. 64, pp. 47-54, 2015.

[4] K. Jugdev, G. Mathur, and T.S. Fung, "Project management assets and their relationship with the project management capability of the firm," International J. of Project Management, vol. 25(6), pp. 560-568, 2007.

[5] M. Perkmann, A. Neely, and K. Walsh, "How should firms evaluate success in university-industry alliances? A performance measurement system,” R\&D Management, vol. 41(2), pp. 202-216, 2011

[6] T. Barnes, I. Bashby, and A. Gibbons, "Effective University - Industry Interaction: A Multi-case Evaluation of Collaborative R\&D Projects," European Management Journal, vol. 20(3), pp. 272-285, 2002.

[7] R. Rohrbeck, and H.M. Arnold, "Making university-industry collaboration work-a case study on the Deutsche Telekom Laboratories contrasted with findings in literature," ISPIM Annual Conference Network Innovation, pp. 1-11, 2009.

[8] S. Pellegrinelli, "What's in a name: Project or programme?," International Journal of Project Management, vol. 29(2), pp. 232-240, 2011.

[9] M. Payne, "Benefits Management: Releasing project value into the business," Project Manager Today, 2007.

[10] C.E. Serra, and M. Kunc, "Benefits Realisation Management and its influence on project success and on the execution of business strategies," International Journal of Project Management, vol. 33(1), pp. 53-66, 2015.

[11] P. Cleaver, "A Practical Guide to Benefit Realisation," in Service Chain Management: Technology Innovation for the Service Business. C. Voudouris, D. Lesaint and G. Owusu , Eds. Heidelberg: Springer, 2008, pp. 271-350.

[12] Project Management Institute, The Standard for Program Management, 3rd ed., Pennsylvania: Project Management Institute, Inc., 2013.

[13] J.v. Brocke, and S. Lippe, "Managing collaborative research projects: A synthesis of project management literature and directives for future research, ” Inter. J. Project Management, vol. 33(5), pp. 1022-1039, 2015.

[14] C. Plewa, and P. Quester, "Key drivers of university-industry relationships: the role of organisational compatibility and personal experience," J. of Services Marketing, vol. 21(5), pp. 370-382, 2007.

[15] Y. Chih, and O. Zwikael, "Project benefit management: A conceptual framework of target benefit formulation," International Journal of Project Management, vol. 33(2), pp. 352-362, 2015.

[16] C.M. Chin, E.H. Yap, and A.C. Spowage, "Project Management Methodology for University-Industry Collaboration Projects," Review of International Comparative Management, vol. 12(5), pp. 901-918, 2011.

[17] S. Ankrah, and O. Al-Tabbaa, "Universities-industry collaboration: A systematic review," Scandinavian J. Man., vol. 31(3), pp. 387-408, 2015.
[18] C. De Fuentes, and G. Dutrénit, "Best channels of academia-industry interaction for long-term benefit," Research Policy, vol. 41(9), pp. 16661682, 2012.

[19] T.A. Barnes, I.R. Pashby, and A.M. Gibbons, "Managing collaborative R\&D projects development of a practical management tool," International Journal of Project Management, vol. 24(5), pp. 395-404, 2006.

[20] Y. Lee, "The Sustainability of University-Industry Research Collaboration: An Empirical Assessment," The Journal of Technology Transfer, vol. 25(2), pp. 111-133, 2000.

[21] D. Mindruta, "Value creation in university-firm research collaborations: A matching approach," Strategic Management Journal, vol. 34(6), pp. 644-665, 2013

[22] HaCIRIC, Benefits Management and Benefits Realisation - Literature Report, United Kingdom: Health and Care Infrastructure Research and Innovation Centre, 2008.

[23] F. Hesselmann, and M. Kunal, "Where are we headed with benefits management research? Current shortcomings and avenues for future research," $22^{\text {th }}$ European Conference on Information Systems, pp.1-17, 2014

[24] S. Sapountzis, J.B. Lima, K.A. Yates, and M. Kagioglou, BeReal-A benefits realisation process from planning to delivery: effective benefits realisation, United Kingdom: University of Salford, 2011.

[25] J. Ward, P. Taylor, and P. Bond, "Evaluation and realisation of IS/IT benefits: an empirical study of current practice," European Journal of Information Systems, vol. 4(4), pp. 214-225, 1996

[26] J. Thorp, The Information Paradox: realising the business benefits of information technology, Toronto, Canada: MacGraw-Hill, 1998.

[27] Office of Government Commerce, Managing Successful Programmes, $4^{\text {th }}$ ed., London: Office of Government Commerce, 2011.

[28] R.K. Yin, Case Study Research: Design and Methods, $5^{\text {th }}$ ed., California, United States of America: Sage Publications, Inc., 2014

[29] M. Saunders, P. Lewis, and A. Thornhil, Research Methods for Business Students, $5^{\text {th }}$ ed., Edinburgh: Pearson Education Limited, 2009.

[30] R. Müller, J. Glückler, and M. Aubry, “A Relational Typology of Project Management Offices," Project Management Journal, vol. 44(1), pp. 5976,2013

[31] K. Artto, I. Kulvik, J. Poskela, and V. Turkulainen, "The integrative role of the project management office in the front end of innovation," International J. of Project Management, vol. 29(4), pp. 408-421, 2011.

[32] G. Fernandes, R.J. Machado, E.B. Pinto, M. Araújo, and A. Pontes, "A Quantitative Study to Assess a Program and Project Management Approach for Collaborative University Industry R\&D Funded Contracts,' 22nd ICE/IEEE International Technology Management Conference, pp. $1-10,2016$

[33] G. Fernandes, E.B. Pinto, J. Machado, M. Araújo, and A. Pontes, "A Program and Project Management Approach for Collaborative University-industry R\&D Funded Contracts," Procedia Computer Science, vol. 64, pp. 1065-1074, 2015.

[34] J. Langford, and D. McDonagh, Focus Groups: Supporting Effective Product Development, New York: Taylor \& Francis, 2003.

[35] A. Draghici, C. Baban, M. Gogan, L. Ivascu, "A Knowledge Management Approach for the University-industry Collaboration in Open Innovation," Procedia Economics and Finance, vol. 23, pp. 23-32, 2015

[36] D.P. Lepak, K.G. Smith, and M.S. Taylor, "Introduction to Special Topic Forum: Value Creation and Value Capture: A Multilevel Perspective,' The Academy of Management Review, vol. 32(1), pp. 180-194, 2007.

[37] W.E. Deming, and D.W. Edwards, Quality, productivity, and competitive position, vol. 183, Massachusetts Institute of Technology, Center for advanced engineering study Cambridge, MA.,1982.

[38] M.Vestola, "A Comparison of Nine Basic Techniques for Requirements Prioritization", Helsinki University of Technology, pp. 1-8, 2010. 